\title{
Lepocreadiidae Odhner, 1905 and Aephnidiogenidae Yamaguti, 1934 (Digenea: Lepocreadioidea) of fishes from Moreton Bay, Queensland, Australia, with the erection of a new family and genus
}

\author{
Rodney A. Bray $\cdot$ Thomas H. Cribb $\cdot$ Scott C. Cutmore
}

Received: 13 March 2018/Accepted: 19 May 2018/Published online: 31 May 2018

(C) The Author(s) 2018

\begin{abstract}
Digeneans of the lepocreadioid families Lepocreadiidae Odhner, 1905 and Aephnidiogenidae Yamaguti, 1934 from Moreton Bay, off southern Queensland, Australia, are recorded, along with the erection of a new family, Gibsonivermidae. Molecular data were generated for all representatives of these families collected during this study and a phylogram for members of the superfamily was generated based on the partial 28S rDNA dataset, placing these species in context with those previously sequenced. This phylogenetic analysis demonstrates that the
\end{abstract}

This article was registered in the Official Register of Zoological Nomenclature (ZooBank) as urn:lsid:zoobank.org: pub:907DBCEC-B908-4135-90AA-3950B0F75DD8. This article was published as an Online First article on the online publication date shown on this page. The article should be cited by using the doi number. This is the Version of Record.

This article is part of the Topical Collection Digenea.

Electronic supplementary material The online version of this article (https://doi.org/10.1007/s11230-018-9803-3) contains supplementary material, which is available to authorized users.

R. A. Bray $(\bowtie)$

Department of Life Sciences, Natural History Museum,

Cromwell Road, London SW7 5BD, UK

e-mail: rab@nhm.ac.uk

T. H. Cribb · S. C. Cutmore

School of Biological Sciences, The University of

Queensland, St Lucia, QLD 4072, Australia monotypic Gibsonivermis Bray, Cribb \& Barker, 1997 is isolated from all other lepocreadioids and supports the erection of Gibsonivermidae n. fam., which is defined morphologically, based particularly on the uniquely elongated male terminal genitalia, the distribution of the uterus in the forebody and the presence of a uroproct. Mobahincia teirae n. g., n. sp. is reported from Platax teira (Forsskål) in Moreton Bay and off Heron Island and New Caledonia. Recognition of this new genus is based on molecular results and the combination of caeca abutting the posterior body wall and the lack of an anterior body scoop or flanges. The following lepocreadioid species are reported from Moreton Bay for the first time: Bianium arabicum Sey, 1996 in Lagocephalus lunaris (Bloch \& Schneider), Diploproctodaeum cf. monstrosum Bray, Cribb \& Justine, 2010 in Arothron hispidus (Linnaeus), Multitestis magnacetabulum Mamaev, 1970 and Neomultitestis aspidogastriformis Bray \& Cribb, 2003 in Platax teira and Opechona austrobacillaris Bray \& Cribb, 1998 in Pomatomus saltatrix (Linnaeus). Bianium plicitum (Linton, 1928) is reported from Torquigener squamicauda (Ogilby) for the first time. Sequences of newly collected specimens of Austroholorchis sprenti (Gibson, 1987) indicate that the species forms a clade with other members of the Aephnidiogenidae, agreeing with its morphology. The phylogenetic status of all newly sequenced species is discussed. 


\section{Introduction}

During January and July 2016, workshops were held at the Moreton Bay Research Station at Dunwich on North Stradbroke Island, off southern Queensland, Australia, as part of a collaborative study of the metazoan parasite fauna of the fishes, particularly the commercially important fishes, of Moreton Bay. The present work is a report on some of the digeneans found, framed as an overview of our knowledge of the closely related families Lepocreadiidae Odhner, 1905 and Aephnidiogenidae Yamaguti, 1934 in Moreton Bay. The lepocreadioid fauna of Australian and other Indo-Pacific fishes has been 'subjected to recent sustained study' (Cribb \& Bray, 2011). This has been documented in some 31 articles (see Bray et al., 2009, and references therein; Bray et al., 2010b; Bray et al., 2010a); however, much work remains to be done. Some genera are large and/or complex and require molecular data to elucidate their status.

Bray \& Cribb (2012) divided members of the Lepocreadiidae Odhner, 1905 as recognised by Bray (2005) into three families based on a molecular phylogeny. These three families, the Lepocreadiidae, Lepidapedidae Yamaguti, 1958 and Aephnidiogenidae Yamaguti, 1934, had previously been considered subfamilies of the Lepocreadiidae (see Bray, 2005). In this paper, we analyse species of two of these three families found in Moreton Bay. A new family and a new genus and species are erected. In addition, this report summarises information from earlier studies in the region. Collections representing specimens of two lepocreadiid genera (Lepotrema Ozaki, 1932 and Preptetos Pritchard, 1960) and one lepidapedid genus (Postlepidapedon Zdzitowiecki, 1993) will be incorporated in genus-specific studies later and are thus not reported here. Novel 28S and ITS2 rDNA sequences are reported for all new collections, which enable the placement of many of the Moreton Bay species in a wider phylogenetic context.

\section{Materials and methods}

\section{Specimen collection and morphological analysis}

Fish were collected by line-fishing, spear-fishing, seine netting and from the commercial tunnel-net fishery in Moreton Bay, Queensland, Australia. Fish were euthanised and examined for trematodes, as described by Cribb \& Bray (2010). Those collected were fixed by pipetting into near-boiling saline and immediately preserved in formalin or $70 \%$ ethanol. Whole-mounts were stained with Mayer's paracarmine or Mayer's haematoxylin, dehydrated in a graded ethanol series, cleared in beechwood creosote or methyl salicylate and mounted in Canada balsam. Measurements were made through a drawing tube on an Olympus BH-2 microscope, using a Digicad Plus digitising tablet and Carl Zeiss KS100 software adapted by Imaging Associates, and are quoted in micrometres, with the range and the mean in parentheses. The following abbreviations are used: NHMUK, Natural History Museum, London, UK; MNHN, Museum National d'Histoire Naturelle, Paris, France; QM, Queensland Museum Collection, Brisbane, Australia.

\section{Molecular sequencing and phylogenetic analysis}

Specimens for molecular analysis were processed according to the protocols used by Sun et al. (2014). The complete ITS2 rDNA region was amplified and sequenced using the primers 3S (Morgan \& Blair, 1995) and ITS2.2 (Cribb et al., 1998) and the partial D1-D3 28S rDNA region using LSU5 (Littlewood, 1994), 300F (Littlewood et al., 2000), ECD2 (Littlewood et al., 1997) and 1500R (Snyder \& Tkach, 2001). Geneious ${ }^{\circledR}$ version 10.2.3 (Kearse et al., 2012) was used to assemble and edit contiguous sequences and the start and end of the ITS2 rDNA region were determined by annotation through the ITS2 Database (Keller et al., 2009; Ankenbrand et al., 2015) using the 'Metazoa' model.

The partial 28S rDNA sequences generated during this study were aligned with sequences of related species of the Lepocreadioidea Odhner, 1905 from GenBank using MUSCLE version 3.7 (Edgar 2004) run on the CIPRES portal (Miller et al., 2010), with ClustalW sequence weighting and UPGMA clustering for iterations 1 and 2. The resultant alignment was refined by eye using MESQUITE (Maddison \& Maddison, 2017). The ends of each sequence were trimmed, and ambiguously aligned regions were identified and masked manually (those constituting more than three bases and present in greater than $5 \%$ of the sequences in the dataset).

Bayesian inference and maximum likelihood analyses of the 28S dataset were conducted to explore relationships among these taxa. Bayesian inference analysis was performed using MrBayes version 3.2.6 
(Ronquist et al., 2012) and maximum likelihood analysis using RAxML version 8.2.10 (Stamatakis, 2014), both run on the CIPRES portal. The best nucleotide substitution model was estimated using jModelTest version 2.1.10 (Darriba et al., 2012). Both the Akaike Information Criterion (AIC) and Bayesian Information Criterion (BIC) predicted the GTR $+\mathrm{I}+\Gamma$ model as the best estimator; Bayesian inference and maximum likelihood analyses were conducted using the closest approximation to this model. Nodal support in the maximum likelihood analysis was estimated by performing 100 bootstrap pseudoreplicates. Bayesian inference analysis was run over 10,000,000 generations (ngen $=10,000,000$ ) with two runs each containing four simultaneous Markov Chain Monte Carlo (MCMC) chains (nchains = 4) and every 1,000th tree saved. Bayesian inference analysis used the following parameters: $n s t=6$, rates $=$ invgamma, ngammacat $=4$, and the priors parameters of the combined dataset were set to ratepr $=$ variable. Samples of substitution model parameters and tree and branch lengths were summarised using the parameters: sump burnin $=3,000$ and sumt burnin $=$ 3,000. Species of the families Cryptogonimidae Ward, 1917 and Apocreadiidae Skrjabin, 1942 were designated as functional outgroup taxa, sensu Bray et al. (2009).

\section{Family Lepocreadiidae Odhner, 1905 Subfamily Lepocreadiinae Odhner, 1905 Genus Bianium Stunkard, 1930}

\section{Bianium plicitum (Linton, 1928) Stunkard, 1931}

Syn. Psilostomum plicitum Linton, 1928

Type-host: Larus argentatus Pontoppidan (Charadriiformes: Laridae), herring gull.

Type-locality: Woods Hole, Massachusetts, USA.

New records:

Hosts: Torquigener squamicauda (Ogilby), brush-tail toadfish; T. pleurogramma (Regan), weeping toado (Tetraodontiformes: Tetraodontidae).

Localities: Ex T. squamicauda, Moreton Banks, Moreton Bay $\left(27^{\circ} 24^{\prime} \mathrm{S}, 153^{\circ} 20^{\prime} \mathrm{E}\right)$; ex T. pleurogramma, off Amity, Moreton Bay $\left(27^{\circ} 24^{\prime} \mathrm{S}\right.$, $\left.153^{\circ} 26^{\prime} \mathrm{E}\right)$.

Site in host: Intestine.

Voucher material: Three specimens in the QM G237251-3, one in the NHMUK 2018.3.26.1.
Representative DNA sequences: ITS2 rDNA, four identical replicates (two in GenBank MH157055MH157056); 28S rDNA, one sequence (GenBank MH157066).

New measurements: Supplementary Table S1.

Remarks

The new specimens (Fig. 1A) are morphologically identical to those reported from Moreton Bay by Bray \& Cribb (1998) from Whitley's toadfish Torquigener whitleyi (Paradice) and T. pleurogramma. New ITS2 rDNA sequences of specimens from T. squamicauda and T. pleurogramma were identical. Analysis of the $28 \mathrm{~S}$ data showed that this species forms a strongly supported clade with similar lepocreadiid species from tetraodontiforms (other species of Bianium, Pelopscreadium Dronen, Blend, Khalifa, Mohamadain \& Karer, 2016, Diplocreadium Park, 1939, Diploproctodaeum La Rue, 1926 and Lobatocreadium Madhavi, 1972); nodal support for relationships within this clade was weak (Fig. 2). The two species of Bianium included in the phylogenetic analyses are paraphyletic with respect to species of Diplocreadium, Diploproctodaeum and Lobatocreadium. The status of these specimens from Moreton Bay as identical to Bianum plicitum as described by Linton (1928) is yet to be tested by DNA sequence comparison, and we think it highly likely that forms from eastern Australian waters are not conspecific with the original specimens from off north-eastern USA.

\section{Bianium arabicum Sey, 1996}

Type-host: Lagocephalus lunaris (Bloch \& Schneider) (Tetraodontiformes: Tetraodontidae), lunartail puffer. Type-locality: Off Kuwait, Arabian Gulf.

New records:

Host: Lagocephalus lunaris.

Locality: Off Wynnum North, Moreton Bay $\left(27^{\circ} 23^{\prime} \mathrm{S}\right.$, $\left.153^{\circ} 11^{\prime} \mathrm{E}\right)$.

Site in host: Intestine.

Voucher material: Two specimens in the QM G237254-5, one in the NHMUK 2018.3.26.2.

Representative DNA sequences: ITS2 rDNA, one sequence (GenBank MH157054); 28S rDNA, one sequence (GenBank MH157076).

New measurements: Supplementary Table S1. 

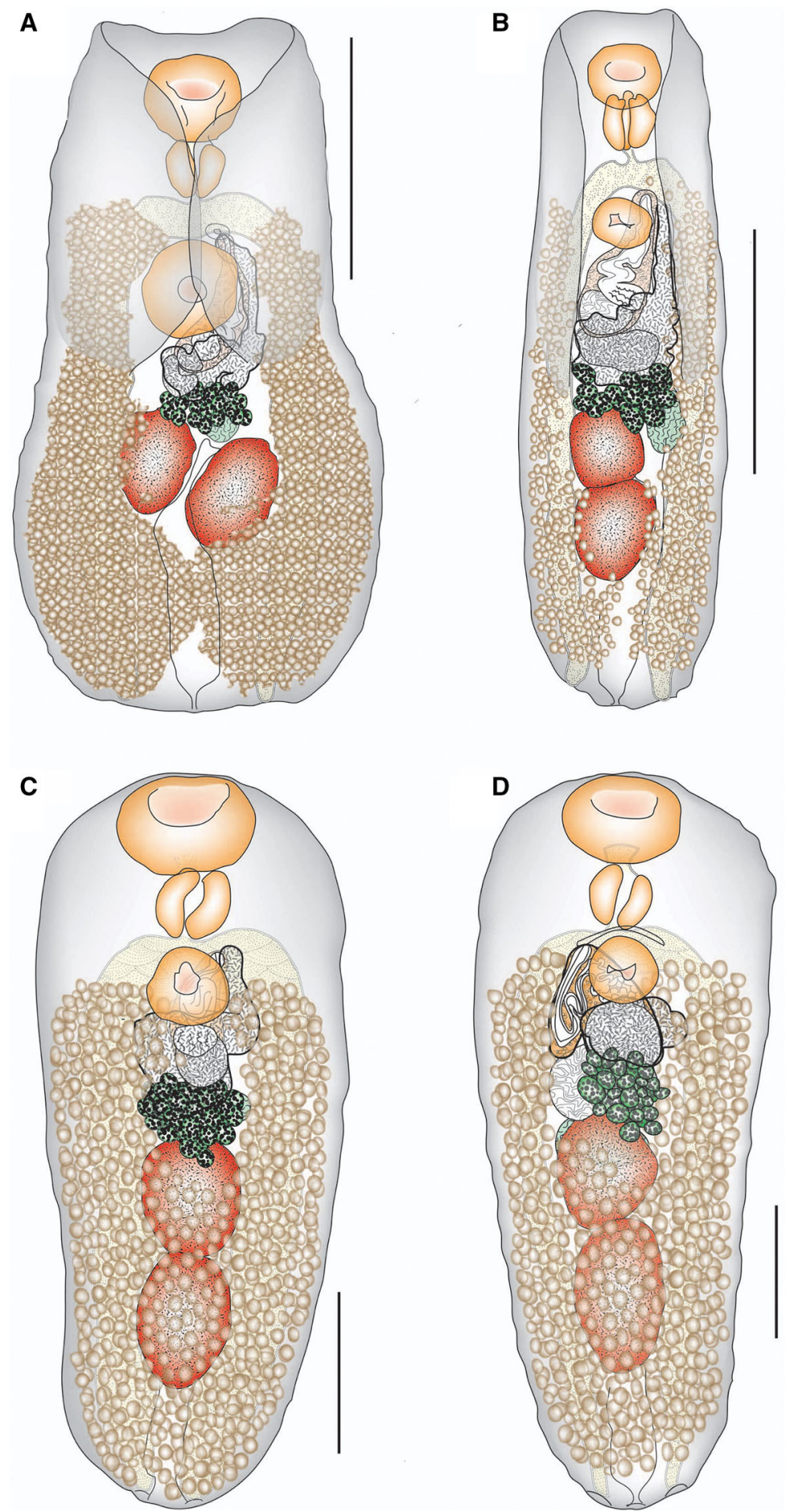

Fig. 1 A, Bianium plicitum (Linton, 1928) ex Torquigener squamicauda, ventral view, uterus in outline; B, Bianium arabicum Sey, 1996 ex Lagocephalus lunaris, ventral view, uterus in outline; C, Mobahincia teirae n. g., n. sp. ex Platax teira, Moreton Bay, ventral view, uterus in outline; D, Mobahincia teirae n. g., n. sp. ex Platax teira, off Heron Island, ventral view, uterus in outline. Scale-bars: A, $\mathrm{B}, 500 \mu \mathrm{m} ; \mathrm{C}, \mathrm{D}, 200 \mu \mathrm{m}$ 
Remarks

In the original description of B. arabicum, Sey (1996) stated 'Along the lateral sides of body longitudinal folds present, bending ventrally and ending at posterior extremity'. The longitudinal folds (flanges) do not appear to reach the full length of the body in our specimens (Fig. 1B). When describing specimens considered to be this species from the silverstripe blaasop Lagocephalus sceleratus (Gmelin) off New Caledonia, Bray et al. (2010a) said 'it has full-length lateral folds of the body (or scoop-sides), although the full extent is not always visible on both sides of the worm'. These authors pointed out the similarity of these worms to those described from L. lunaris by Hafeezullah (1970) under the name B. plicitum (Linton, 1928) from off Chennai (as Madras) in the Bay of Bengal and by Shen \& Tong (1990) under the name B. dayawanense Shen \& Tong, 1990 from Daya Bay, China [in this case the host is quoted as L. lunaris spadiceus (Richardson)]. The lateral flanges of the Bay of Bengal worms are similar to those seen in our specimens and the dimensions are close to those found by Sey (1996) and Bray et al. (2010a) (Supplementary Table S1). The Chinese worms tend to be larger and the flanges are illustrated as distinct flaps reaching only to the ventral sucker level. It is not possible to be certain of the status of all these forms, but it appears that the Bay of Bengal specimens are more similar to the worms here considered B. arabicum. This is the first report of $B$. arabicum from Moreton Bay.

Analysis of the $28 \mathrm{~S}$ data showed that this species forms a strongly-supported clade with similar lepocreadiid species from tetraodontiforms; nodal support for relationships within this clade were weak (Fig. 2) and, as discussed above, the two species of Bianium did not form a clade.

\section{Genus Clavogalea Bray, 1985}

\section{Clavogalea trachinoti (Fischthal \& Thomas, 1968) Bray \& Gibson, 1990}

Syns Stephanostomum trachinoti Fischthal \& Thomas, 1968; Opechona pseudobacillaris Fischthal \& Thomas, 1970

Type-host: Trachinotus goreensis Cuvier (Perciformes: Carangidae), longfin pompano.

Type-locality: Off Iture, Elmina, Ghana.
New records:

Host: Trachinotus coppingeri Günther (Perciformes: Carangidae), swallowtail dart.

Locality: Off Green Island, Moreton Bay $\left(27^{\circ} 25^{\prime} \mathrm{S}\right.$, $\left.153^{\circ} 14^{\prime} \mathrm{E}\right)$.

Site in host: Intestine.

Voucher material: Six specimens in the QM G237275-80.

Representative DNA sequences: ITS2 rDNA, three replicates (one in GenBank MH157057); 28S rDNA, one sequence (GenBank MH157067).

Remarks

Bray \& Gibson (1990) redescribed the original specimens of Stephanostomum trachinoti Fischthal \& Thomas, 1968 and its synonym Opechona pseudobacillaris Fischthal \& Thomas, 1970, and placed the species in Clavogalea. Bray \& Cribb (1998) redescribed the worm based on new material from the large-spotted dart Trachinotus botla (Shaw) off Heron Island (southern Great Barrier Reef) and T. coppingeri Günther off northern New South Wales and in Moreton Bay. Our newly collected material appears identical to these descriptions. New 28S rDNA data were identical to sequences reported by Bray et al. (2009) based on specimens from $T$. coppingeri collected off Heron Island. Phylogenetic analysis of the $28 \mathrm{~S}$ dataset indicates that, of taxa available for analysis, this species is most closely related to Preptetos trulla (Linton, 1907), Prodistomum keyam Bray \& Cribb, 1996, Opechona austrobacillaris Bray \& Cribb, 1998 and Opechona kahawai Bray \& Cribb, 2003. These five species formed a clade in the phylogenetic analysis with $C$. trachinoti as sister to a clade of the other four species; however, nodal support for this topology was poor (Fig. 2).

\section{Genus Diplocreadium Park, 1939}

\section{Diplocreadium tangaloomaense Bray, Cribb \& Barker, 1996 (emend.)}

Type-host: Paramonacanthus japonicus (Tilesius) (Tetraodontiformes: Monacanthidae), hairfinned leatherjacket.

Type-locality: Off Tangalooma, Moreton Bay, Queensland. 


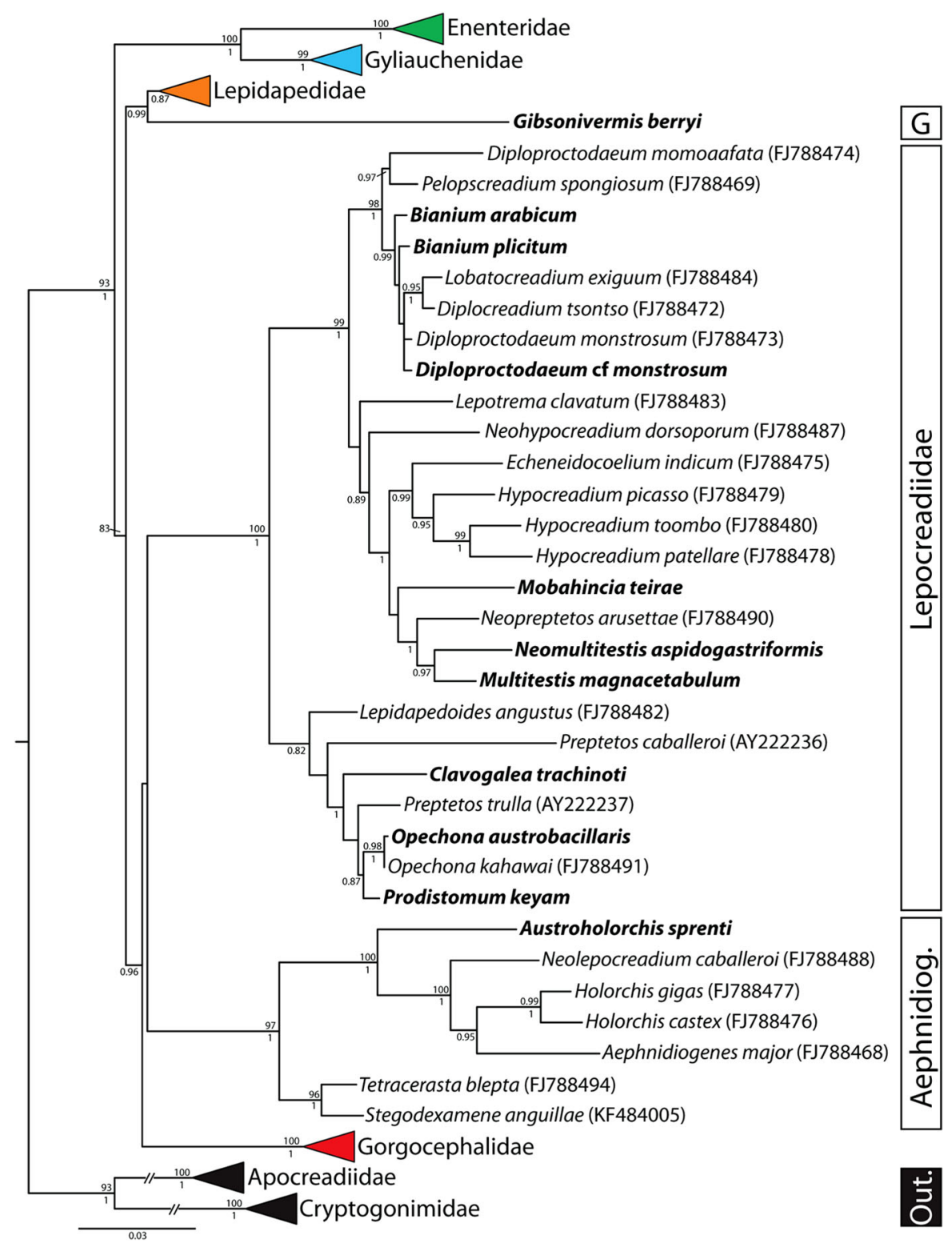

Fig. 2 Relationships between members of the seven families of the superfamily Lepocreadioidea based on maximum likelihood analysis of the partial 28S rDNA dataset. Species from Moreton Bay are shown in bold and clades representing the Enenteridae, Gorgocephalidae, Gyliauchenidae and Lepidapedidae are collapsed for brevity. Maximum likelihood bootstrap support values are shown above the nodes and Bayesian inference posterior probabilities below. Support values $<80$ and $<0.80$ are not shown. Outgroup taxa are species of the Apocreadiidae and Cryptogonimidae. Abbreviations: Aephnidiog., Aephnidiogenidae; G, Gibsonivermidae; Out., outgroup taxa

\section{Remark}

This species has not been detected since its original description and no material is available for molecular characterisation.

\section{Diploproctodaeum monstrosum Bray, Cribb \& Justine, 2010}

Type-host: Arothron stellatus (Anonymous) (Tetraodontiformes: Tetraodontidae), stellate puffer. 
Type-locality: Off Mermaid Beach, Lizard Island, Queensland, Australia.

\section{Diploproctodaeum cf. monstrosum}

New records

Host: Arothron hispidus (Linnaeus), white-spotted puffer.

Locality: Off Peel Island, Moreton Bay $\left(27^{\circ} 30^{\prime} \mathrm{S}\right.$, $\left.153^{\circ} 20^{\prime} \mathrm{E}\right)$.

Site: Intestine.

Voucher material: Three specimens in the QM G237281-3.

Representative DNA sequences: ITS2 rDNA, two replicates (one in GenBank MH157059); 28S rDNA, one sequence (GenBank MH157069).

Remarks

Bray et al. (2010a) reported this species in Arothron stellatus and A. mappa from off Lizard Island. They pointed out that the sequence of 'Diploproctodaeum sp.' from A. stellatus off Lizard Island (GenBank FJ788474), used in the study of Bray et al. (2009), referred to this species. 28S sequence data generated from the new Moreton Bay material differs from that sequence by 5 bases. No morphological differences could be detected between the two collections, but only a relatively small number of specimens has been collected and the rather amorphous structure of these worms makes morphological comparisons difficult. Given that the two sites are only approximately $1,650 \mathrm{~km}$ apart, a 5 bp difference in the $28 \mathrm{~S}$ rDNA raises the possibility of the presence or more than one species. However, we consider the current evidence insufficient to suggest that specimens from Moreton Bay represent a species distinct from that occurring on the northern Great Barrier Reef but consider the issue worthy of further consideration in the light of additional genetic data from more variable gene regions (Blasco-Costa et al., 2016). For the present, the designation $D$. cf. monstrosum seems the best way to draw attention to these issues.

\section{Diploproctodaeum yosogi Bray, Cribb \& Barker, 1996}

Type-host: Paramonacanthus japonicus (Tilesius) (Tetraodontiformes: Monacanthidae), hairfinned leatherjacket.
Type-locality: Off Mud Island, Moreton Bay, Queensland.

Remark

This species has not been detected since its original description and no material is available for molecular characterisation.

Genus Lepocreadioides Yamaguti, 1936

Syn. Bicaudum Bilqees, 1971

\section{Lepocreadioides orientalis Park, 1939}

Type-host: Cynoglossus joyneri Günther, red tonguesole (Pleuronectiformes: Cynoglossidae).

Type-locality: Off Simmi Island, North Tyôsen, Korea.

Remark

This species has not been re-collected from Moreton Bay since the report from the fourlined tonguesole Cynoglossus bilineatus (Lacépède) by Bray \& Cribb (1998) and no material is available for molecular characterisation.

\section{Genus Mobahincia n. g.}

\section{Diagnosis}

Body broader anteriorly, tapering posteriorly. Tegument spined. Eye-spot pigment scattered at pharyngeal level. Oral sucker transversely oval, subterminal. Ventral sucker rounded, smaller than oral sucker, in anterior quarter of body-length. Prepharynx short. Pharynx oval. Oesophagus not detected. Intestinal bifurcation dorsal to anterior part of ventral sucker or just in forebody. Caeca straight, reaching to posterior extremity where they abut body wall at base on small indentations; ani possibly present. Testes two, oval, entire, tandem contiguous, in mid-hindbody. External seminal vesicle large, saccular, dorsal to uterus. Cirrus-sac claviform. Internal seminal vesicle large, oval, curved. Pars prostatica oval vesicular, lined with anuclear cell-like bodies. Ejaculatory duct thickwalled muscular, long, complexly folded. Genital atrium small. Genital pore sinistral to antero-sinistral to ventral sucker. Ovary multilobate, immediately pretesticular. Seminal receptacle canalicular. Mehlis' 
gland dorsal to ovary. Uterus between ovary and ventral sucker, intracaecal. Eggs tanned, operculate. Vitellarium in follicular fields at ventral sucker level and in hindbody. Parasites in intestine of ephippid fishes.

Type-species: Mobahincia teirae n. sp.

Etymology: The generic name is a feminine noun derived from the localities at which this genus has been found: Moreton Bay (Moba), Heron Island (hi), New Caledonia (nc).

ZooBank registration: To comply with the regulations set out in article 8.5 of the amended 2012 version of the International Code of Zoological Nomenclature (ICZN, 2012), details of the new genus have been submitted to ZooBank. The Life Science Identifier (LSID) for Mobahincia n. g. is urn:lsid: zoobank.org:act:8543D3CA-81FC-43A7-9ACB-6BA 5DE6D6BA4.

\section{Remarks}

The species on which this new genus is based appears morphologically closely related to members of Diploproctodaeum and Bianium in having its caeca abutting the posterior body wall, giving the appearance of ani, the usual condition in species of the latter genera; however, there is no indication of an anterior scoop as is usually present in these taxa. Molecular evidence suggests unambiguously that the new genus is not closely related to members of these two genera. The exact relationship of this species is not well resolved in the phylogram derived from the $28 \mathrm{~S}$ analyses of the currently available lepocreadiid sequences (many relationships within the family have poor support), but it is clear that it does not resolve within the well-supported clade which includes Diploproctodaeum and Bianium species (Fig. 2). Following the key to the Lepocreadiidae produced by Bray (2005), the species appears closest to members of Lobatocreadium or Pseudocreadium Layman, 1930; the new genus differs from both in the presence of long caeca abutting the body-wall and the terminal excretory pore. The vitellarium is more extensive in both species of Lobatocreadium and Pseudocreadium, and in members of the latter genus the testes are symmetrical. We conclude that the relationships of this form are best expressed by the erection of a new genus.

\section{Mobahincia teirae n. sp.}

Type-host: Platax teira (Forsskål) (Perciformes: Ephippidae), longfin batfish.

Type-locality: Four Beacons, Moreton Bay $\left(27^{\circ} 10^{\prime} \mathrm{S}\right.$, $\left.153^{\circ} 21^{\prime} \mathrm{E}\right)$.

Other localities: Off Heron Island $\left(23^{\circ} 27^{\prime} \mathrm{S}\right.$, $\left.151^{\circ} 55^{\prime} \mathrm{E}\right)$; Nouméa Fish Market, New Caledonia.

Site in host: Intestine.

Type-material: Holotype QM G237256 and 12 paratypes QM G237257-60, NHMUK 2018.3.26.5-8.

Voucher material: Off Heron Island: QM G237261; off New Caledonia: MNHN JNC2872F.

Representative DNA sequences: ITS2 rDNA, five replicates (one in GenBank MH157058); 28S rDNA, one sequence (GenBank MH157068).

ZooBank registration: To comply with the regulations set out in article 8.5 of the amended 2012 version of the International Code of Zoological Nomenclature (ICZN, 2012), details of the new species have been submitted to ZooBank. The Life Science Identifier (LSID) for Mobahincia teirae n. sp. is urn:lsid:zoobank.org:act:7FD7D6C8-D114-4C5E-BEDAE25CB81979E9.

Etymology: The specific epithet is derived from that of the host species.

Description (Fig. 1C, D)

[Based on 7 ovigerous and seven non-ovigerous specimens from Moreton Bay, 1 specimen from off Heron Island and 1 specimen from off New Caledonia; measurements given in Table 1.] Body broader anteriorly, tapering posteriorly. Body spines small on anterior 'shoulders', much more robust along remainder of body, reach close to posterior extremity. Eyespot pigment scattered at pharyngeal level. Oral sucker transversely oval, subterminal. Ventral sucker rounded, smaller than oral sucker, in anterior quarter of body-length. Prepharynx short, mainly in posterior concavity of oral sucker. Pharynx oval. Oesophagus not detected. Intestinal bifurcation dorsal to anterior 
Table 1 Measurements and ratios of Mobahincia teirae ex Platax teira

\begin{tabular}{|c|c|c|c|c|}
\hline \multirow[t]{2}{*}{ Locality } & \multicolumn{2}{|l|}{ Moreton Bay $(n=7)$} & \multirow{2}{*}{$\begin{array}{l}\text { New Caledonia } \\
(\mathrm{n}=1)\end{array}$} & \multirow{2}{*}{$\begin{array}{l}\text { Heron Island } \\
(\mathrm{n}=1)\end{array}$} \\
\hline & Range & Mean & & \\
\hline Body & $685-1,018 \times 344-427$ & $834 \times 383$ & $750 \times 395$ & $1,013 \times 415$ \\
\hline Forebody length & $186-234$ & 204 & 214 & 221 \\
\hline Pre-oral lobe length & $0-5$ & 3 & 6 & 5 \\
\hline Oral sucker & $104-141 \times 148-190$ & $125 \times 170$ & $127 \times 179$ & $115 \times 170$ \\
\hline Prepharynx length & $0-35$ & 5 & 0 & 8 \\
\hline Pharynx & $82-100 \times 80-105$ & $90 \times 89$ & $107 \times 97$ & $84 \times 86$ \\
\hline Oesophagus length & 0 & & 18 & 24 \\
\hline $\begin{array}{l}\text { Distance from intestinal bifurcation to ventral sucker } \\
\text { (IB-VS) }\end{array}$ & $0-16$ & 4 & 0 & 0 \\
\hline Distance from vitellarium to ventral sucker & 0 & 0 & 19 & 0 \\
\hline Ventral sucker & $79-112 \times 90-122$ & $96 \times 103$ & $89 \times 98$ & $93 \times 99$ \\
\hline Cirrus-sac & $129-189 \times 71-90$ & $158 \times 79$ & $121 \times 44$ & $175 \times 56$ \\
\hline Distance from external seminal vesicle to ventral sucker & $85-118$ & 102 & 70 & 169 \\
\hline Distance from ventral sucker to ovary (VS-Ov) & $20-51$ & 34 & 17 & 61 \\
\hline Ovary & $84-115 \times 112-169$ & $102 \times 134)$ & $64 \times 110$ & $132 \times 133$ \\
\hline Distance from ovary to anterior testis & 0 & 0 & 0 & 0 \\
\hline Anterior testis & $118-144 \times 123-147$ & $128 \times 131$ & $112 \times 141$ & $163 \times 137$ \\
\hline Distance between testes & 0 & 0 & 0 & 0 \\
\hline Posterior testis & $106-214 \times 107-137$ & $157 \times 121$ & $125 \times 144$ & $209 \times 129$ \\
\hline Post-testicular distance & $112-190$ & 150 & 128 & 190 \\
\hline Post-caecal distance & $0-25$ & 5 & 0 & 0 \\
\hline Eggs & $58-70 \times 26-41$ & $62 \times 34$ & $63 \times 23$ & $69 \times 33$ \\
\hline Width $(\%)$ & $41.9-59.0$ & 46.5 & 52.7 & 41.0 \\
\hline Forebody (\%) & $21.8-27.2$ & 24.7 & 28.5 & 21.8 \\
\hline Sucker length ratio & $1: 0.67-0.90$ & $1: 0.77$ & $1: 0.70$ & $1: 0.81$ \\
\hline Sucker width ratio & $1: 0.58-0.64$ & $1: 0.60$ & $1: 0.55$ & $1: 0.58$ \\
\hline Oral sucker: pharynx width & $1: 1.72-2.09$ & $1: 1.92$ & $1: 1.84$ & $1: 1.98$ \\
\hline Ventral sucker to ovary (\%) & $2.63-5.02$ & 4.04 & 2.32 & 6.06 \\
\hline External seminal vesicle to ventral sucker as $\%$ of VS-Ov & $283-418$ & 351 & 403 & 274 \\
\hline Post-testicular distance $(\%)$ & $16-20$ & 18 & 17.1 & 18.8 \\
\hline Prepharynx $(\%)$ & $0-16.4$ & 2.34 & 0 & 3.51 \\
\hline Oesophagus (\%) & 0 & 0 & 2.37 & 2.37 \\
\hline Distance IB-VS (\%) & $0-1.76$ & 0.50 & 0 & 0 \\
\hline Vitellarium to ventral sucker distance $(\%)$ & 0 & 0 & 2.47 & 0 \\
\hline Ovary to anterior testis $(\%)$ & 0 & 0 & 0 & 0 \\
\hline Distance between testes $(\%)$ & 0 & 0 & 0 & 0 \\
\hline Cirrus-sac length (\%) & $16.4-22.0$ & 19.0 & 16.2 & 17.2 \\
\hline Pre-vitelline distance & $186-234$ & 204 & 195 & 221 \\
\hline Pre-vitelline distance $(\%)$ & $21.8-27.2$ & 24.7 & 26.0 & 21.8 \\
\hline Oesophagus length as $\%$ of forebody length & 0 & 0 & 8.33 & 10.9 \\
\hline Distance IB-VS as \% of forebody length & $0-7.31$ & 2.02 & 0 & 0 \\
\hline $\begin{array}{l}\text { Vitellarium to ventral sucker distance as } \% \text { of } \\
\text { forebody length }\end{array}$ & 0 & 0 & 8.66 & 0 \\
\hline
\end{tabular}

Note: (\%), percent of body-length where not otherwise noted; IB-VS, intestinal bifurcation to ventral sucker distance. Where length is followed by width, the two are separated by an ' $x$ ' 
part of ventral sucker or just in forebody. Caeca straight, reach to posterior extremity where they abut body wall at base on small indentations; ani possibly present.

Testes 2, oval, entire, tandem contiguous, in midhindbody. External seminal vesicle large, saccular, dorsal to uterus. Cirrus-sac claviform. Internal seminal vesicle large, oval, curved. Pars prostatica oval vesicular, lined with anuclear cell-like bodies. Ejaculatory duct thick-walled, muscular, long, complexly folded. Genital atrium small. Genital pore closely sinistral to antero-sinistral to ventral sucker.

Ovary multilobate (about 14-20 lobes), immediately pre-testicular. Seminal receptacle saccular, dorsal to anterior testis. Laurer's canal not detected. Mehlis' gland dorsal to ovary. Uterus between ovary and ventral sucker, intracaecal. Eggs tanned, operculate. Vitellarium follicular, in extensive dorsal and ventral fields, from level of ventral sucker to posterior extremity; fields confluent at level of testes and in post-testicular region.

Excretory pore terminal; excretory vesicle narrow posteriorly, widens abruptly and reaches at least to posterior testes.

\section{Remarks}

Several species of Diploproctodaeum are found in Platax spp., namely D. plataxi Mamaev, 1970, D. rutellum (Mamaev, 1970) and D. tsubameuo Bray \& Cribb, 2003; all three species have caeca abutting the body-wall and are often described as having ani (Mamaev, 1970; Bray \& Cribb, 2003a). Other lepocreadiid species from Platax spp., such as Deraiotrema platacis Machida, 1982, Neomultitestis palauensis Machida, 1982 and N. aspidogastriformis Bray \& Cribb, 2003 are also described as having ani or the appearance of ani (Machida, 1982; Bray \& Cribb, 2003a).

Phylogenetic analysis of the $28 \mathrm{~S}$ dataset showed that this species does not form a strongly-supported clade with any particular clade of lepocreadiids. The new species was sister to a clade including Neopreptetos arusettae Machida, 1982, Multitestis magnacetabulum Mamaev, 1970 and Neomultitestis aspidogastriformis, the latter two of which are Platax-infecting species; however, nodal support for this relationship was poor. The new species was not closely related to species of other genera which have similar caecal terminations, namely Diploproctodaeum, Bianium and Pelopscreadium.

\section{Genus Multitestis Manter, 1931}

\section{Multitestis magnacetabulum Mamaev, 1970}

Type-host: Platax orbicularis (Forsskål) (first host listed) (Perciformes: Ephippidae), orbicular batfish. Type-locality: Gulf of Tonkin.

New records:

Host: Platax teira (Forsskål) (Perciformes: Ephippidae), longfin batfish.

Locality: Four Beacons, Moreton Bay $\left(27^{\circ} 10^{\prime} \mathrm{S}\right.$, $\left.153^{\circ} 21^{\prime} \mathrm{E}\right)$.

Site in host: Intestine.

Voucher material: Six voucher specimens QM G237262-7, three NHMUK 2018.3.26.9-11.

Representative DNA sequences: ITS2 rDNA, two replicates (one in GenBank MH157061); 28S rDNA, one sequence (GenBank MH157071).

New measurements: Supplementary Table S2.

\section{Remarks}

This is the first record of this species from Moreton Bay. Bray \& Cribb (2003a) reported it from Platax teira off Heron Island and Bray et al. (2009) used sequences from that collection in their molecular study of the superfamily Lepocreadioidea. 28S sequence data generated from new collections from Moreton Bay differed from the Heron Island specimens (GenBank FJ788485) by a single base. A single base difference is consistent with the minor geographical variation found between these locations for other trematodes (e.g. Cutmore et al., 2016; Brooks et al., 2017); however, given that this single base difference (an A to $\mathrm{T}$ transversion) is within the in the first 15 bases of the start of the sequence, and that this base position is an $\mathrm{A}$ in all other taxa included in the analysis, we predict that the difference in FJ788485 is a sequencing misread. This species has also been reported from the same host in the waters off New Caledonia by Bray \& Justine (2012).

\section{Genus Neomultitestis Machida, 1982}

\section{Neomultitestis aspidogastriformis Bray \& Cribb, 2003}

Type-host: Platax teira (Forsskål) (Perciformes: Ephippidae), longfin batfish.

Type-locality: Off Heron Island, Queensland, Australia. New records 
Host: Platax teira.

Locality: Four Beacons, Moreton Bay $\left(27^{\circ} 10^{\prime} \mathrm{S}\right.$, $\left.153^{\circ} 21^{\prime} \mathrm{E}\right)$.

Site in host: Intestine.

Voucher material: One voucher specimen lodged in the QM G237268.

Representative DNA sequences: ITS2 rDNA, one sequence (GenBank MH157062); 28S rDNA, one sequence (GenBank MH157072).

New measurements: Supplementary Table S2.

Remarks

Bray \& Cribb (2003a) reported this species from P. teira off Heron Island, and Bray et al. (2009) used $28 \mathrm{~S}$ rDNA sequences from that collection in their molecular study of the superfamily Lepocreadioidea. This is the first report of $N$. aspidogastriformis from Moreton Bay. New 28S data generated from Moreton Bay specimens were identical to those of this species off Heron Island (GenBank FJ788489).

\section{Genus Opechona Looss, 1907}

\section{Opechona austrobacillaris Bray \& Cribb, 1998}

Type-host: Pomatomus saltatrix (Linnaeus), tailor (Perciformes: Pomatomidae).

Type-locality: Off South Mole, Fremantle, Western Australia.

New material:

Host: Pomatomus saltatrix.

Locality: Off Garden Island, Moreton Bay $\left(27^{\circ} 36^{\prime} \mathrm{S}\right.$, $\left.153^{\circ} 20^{\prime} \mathrm{E}\right)$.

Site in host: Intestine.

Voucher material: Two specimens in the QM G237269-70, one in the NHMUK 2018.3.26.3.

Representative DNA sequences: ITS2 rDNA, two replicates (one in GenBank MH157063); 28S rDNA, one sequence (GenBank MH157073).

New measurements: Supplementary Table S2.

Remarks

This is the first report of this species from Moreton Bay. Although the type-locality is off Western Australia, the original description also reported and described this species from the eastern coast of Australia, off Iluka in New South Wales (Bray \&
Cribb, 1998). Our specimens from Moreton Bay are indistinguishable from those described by Bray \& Cribb (1998), and we are confident that the new specimens are conspecific with those from off Fremantle and Iluka.

New 28S sequence data generated for O. austrobacillaris differs from those of $O$. kahawai, from Arripis sp. off Tasmania, by just a single base. Unfortunately, no ITS2 rDNA sequence data (a superior marker for species delineation) are available for the Tasmanian species. Bray \& Cribb (2003b) distinguished these two species by the sucker-ratio and the pseudoesophagus/oesophagus length ratio, and by the forebody being proportionally much longer in $O$. kahawai (40-44 vs 28-35\% of body length) (Supplementary Table S2; Bray \& Cribb, 1998). Given the minor genetic differences, the relationship between these two morphologically distinct forms warrants further study. Phylogenetic analysis of the 28S dataset showed these two species of Opechona to be most closely related to Prodistomum keyam; however, nodal support for this clade was poor.

\section{Genus Prodistomum Linton, 1910}

\section{Prodistomum keyam Bray \& Cribb, 1996}

Type-host: Monodactylus argenteus (Linnaeus) (Perciformes: Monodactylidae), silver moony.

Type-locality: Off Hope Island, Queensland, Australia.

New records:

Host: Monodactylus argenteus.

Locality: In Port of Brisbane Land Reclamation, Moreton Bay $\left(27^{\circ} 21^{\prime} \mathrm{S}, 153^{\circ} 11^{\prime} \mathrm{E}\right)$; off Amity, Moreton Bay $\left(27^{\circ} 24^{\prime} \mathrm{S}, 153^{\circ} 26^{\prime} \mathrm{E}\right)$.

Site in host: Intestine.

Voucher material: Four specimens in the QM G237271-4, one in the NHMUK 2018.3.26.3.

Representative DNA sequences: ITS2 rDNA, three identical replicates (one in GenBank MH157064); $28 \mathrm{~S}$ rDNA, one sequence (GenBank MH157074).

New measurements: Supplementary Table S2.

Remarks

Bray \& Cribb (1996) and Bray et al. (2009) reported this host/species combination in Moreton Bay. Bray et al. (2009) used sequences of this species from this host in Moreton Bay in their molecular study of the 
superfamily Lepocreadioidea. Molecular data from new specimens collected in this study were identical to those (FJ788493) from Bray et al. (2009). Phylogenetic analysis of the $28 \mathrm{~S}$ dataset showed P. keyam to be most closely related to Opechona austrobacillaris and O. kahawai, but with low support (Fig. 2). Bray \& Justine (2012) reported this species from the same host from the waters around New Caledonia.

\section{Family Gibsonivermidae n. fam.}

\section{Diagnosis}

Body elongate-oval, flattened. Tegument armed with small spines. Oral sucker subglobular, subterminal. Ventral sucker rounded, pre-equatorial. Prepharynx distinct. Pharynx oval. Oesophagus distinct. Intestinal bifurcation in mid-forebody. Caeca form uroproct at posterior extremity. Testes two, lobed to almost entire, tandem, slightly separated, in mid-hindbody. External seminal vesicle very elongate, tubular, coiled, reaches well into hindbody. Cirrus-sac long, attenuated, coiled proximally. Internal seminal vesicle tubular, coiled. Pars prostatica long, narrow. Ejaculatory duct elongate, muscular, expands distally. Genital atrium small. Genital pore dextrally submedian, ventral to pharynx. Ovary with 4-6 lobes, pretesticular, slightly separated from anterior testis. Seminal vesicle between ovary and anterior testis. Uterus pre-ovarian, intercaecal; lateral slings extend into forebody. Metraterm narrow. Vitellarium follicular; fields reach from anterior region of hindbody or ventral sucker to posterior extremity. Excretory vesicle I-shaped, reaches anterior testis. In intestine of marine teleosts.

Type-genus: Gibsonivermis Bray, Cribb \& Barker, 1997.

ZooBank registration: To comply with the regulations set out in article 8.5 of the amended 2012 version of the International Code of Zoological Nomenclature (ICZN, 2012), details of the new family have been submitted to ZooBank. The Life Science Identifier (LSID) for Gibsonivermidae n. fam. is urn:lsid:zoobank.org:act:F50B45FB-6B41-44B4-8FD25042D1AD938F.

\section{Remarks}

Bray et al. (1997), in proposing Gibsonivermis, stated that it is 'not immediately clear to which subfamily this genus belongs', and Bray \& Cribb (2012) considered Gibsonivermis a genus 'incertae sedis within the superfamily' Lepocreadioidea and 'too enigmatic to allow confident placement'. Barker et al. (1993) sequenced the D1 domain of the 28S ribosomal RNA gene of the type-species of this new taxon under its old name Intusatrium berryi Gibson, 1987 but did not apparently submit the sequence to GenBank (it is itemised in the paper). In the early days of the development of molecular studies, few digenean sequences were available. The tree produced by Barker et al. (1993) included two other lepocreadioids, Gyliauchen sp. (Gyliauchenidae) and Tetracerasta blepta Watson, 1984 (Aephnidogenidae), which clustered with Gibsonivermis, but they stated that 'evidence for the monophyly of the two lepocreadiids [Tetracerasta and Gibsonivermis] was weak'. The molecular phylogeny inferred from $28 \mathrm{~S}$ data reported here confirms that Gibsonivermis does not belong to any of the six accepted lepocreadioid families (i.e. Lepocreadiidae, Aephnidiogenidae, Enenteridae, Gorgocephalidae, Gyliauchenidae, Lepidapedidae; see Bray \& Cribb, 2012), constituents of which all form strongly supported clades. It is distinct enough, both morphologically and genetically, to warrant the proposal of a new family. In the current analyses, the Gibsonivermidae was sister to the Lepidapedidae, with branch lengths between the two families similar to those found between the Lepocreadiidae and Aephnidiogenidae, and the Enenteridae and Gyliauchenidae, indicative of a family level distinction.

Gibsonivermis berryi (Gibson, 1987) Bray, Cribb \& Barker, 1997 has several features very unusual for species within the superfamily, the most striking of which is the form of the male terminal genitalia (Fig. 3A, B). The cirrus-sac is elongate, narrow, coiled proximally and contains a long tubular coiled internal seminal vesicle, a long narrow pars prostatica and a muscular ejaculatory duct which widens distally (Gibson, 1987). The external seminal vesicle is long, tubular and coiled and merges into the internal seminal vesicle. Gibson (1987) described a constriction of the seminal vesicle as it enters the cirrus-sac but stated that it was only seen in sections. We have not been able to detect this constriction in whole-mounted worms. If it is always present, it is obscured by the folds of the seminal vesicle in the region dorsal to the ventral sucker in all the specimens we examined. This folding also usually obscures the precise posterior extent of the cirrus-sac wall. Other distinguishing features, 
which are rare or absent in other lepocreadioids, include a uroproct and a significant proportion of the uterus in the forebody. At present, no other lepocreadioids appear to have characters in any way resembling those of specimens of Gibsonivermis.

The single species of Gibsonivermis is so far known only from Moreton Bay and off Heron Island on the southern Great Barrier Reef. Bray et al. (1999) summarised the knowledge of the parasites of the Sillaginidae and found that no 'lepocreadiids' were reported outside Australian waters, but that in this region a few unusual, apparently endemic, forms occurred, namely species of Gibsonivermis, Austroholorchis Bray \& Cribb, 1997 and Lepidapedella
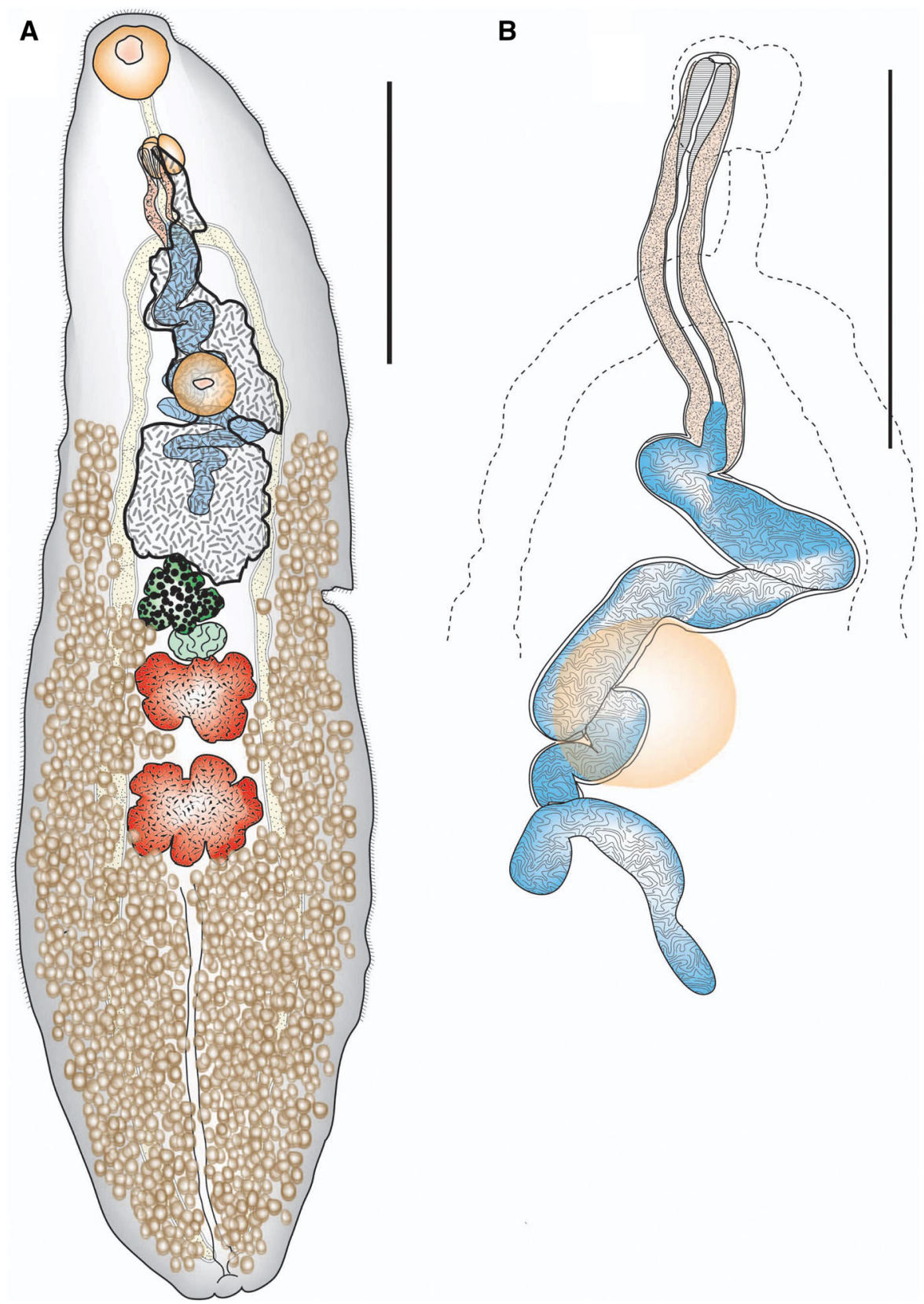

Fig. 3 A, Gibsonivermis berryi (Gibson, 1987) ex Sillago ciliata. Holotype, ventral view, uterus in outline; B, Gibsonivermis berryi (Gibson, 1987) ex Sillago analis. Male terminal genitalia, with ventral sucker and gut in outline. Scale-bars: A, 1,000 $\mu \mathrm{m} ; \mathrm{B}, 500 \mu \mathrm{m}$ 
Bray, Cribb \& Pichelin, 1999. Austroholorchis is now known to be an aephnidiogenid (see below). Lepidapedella is an unusual worm, which likewise does not agree well with any lepocreadioid family, but shows no morphological similarities to G. berryi, and was placed in the Lepidapedidae by Bray \& Cribb (2012). The species of endemic Australian lepocreadioid genera which are not reported from sillaginids include the lepocreadiids Amphicreadium Bray \& Cribb, 2001, Cliveus Bray \& Cribb, 1997 and Rugocavum Bray \& Cribb, 1997, the lepidapedids Harveytrema Kruse, 1979 and Scaphatrema Bray \& Cribb, 1997, and the unassigned Paraneocreadium Kruse, 1978 and Jericho Bray \& Cribb, 1997 (Kruse, 1978, 1979; Bray \& Cribb, 1997a, 2001, 2012). None of members of these genera exhibit any great similarity to $G$. berryi, although the single species of Paraneocreadium has some extension of the uterus into the forebody and the testes are lobed (Kruse, 1978, 1979; Bray \& Cribb, 1997a). Considering the recognition that Gibsonivermis warrants a separate family-level status within the Lepocreadioidea, the phylogenetic status of these other distinctive, apparent "southern endemics", is of great interest. Since 1999, only records of opecoelids and transversotrematids have been added to the known sillaginid digenean fauna (Aken'Ova, 2003; Aken'Ova et al., 2008; Cutmore et al., 2016).

\section{Genus Gibsonivermis Bray, Cribb \& Barker, 1997}

\section{Gibsonivermis berryi (Gibson, 1987) Bray, Cribb \& Barker, 1997}

Syn. Intusatrium berryi Gibson, 1987

Type-host: Sillago ciliata Cuvier (Perciformes: Sillaginidae), sand whiting.

Type-locality: Deception Bay, off Moreton Bay.

New record:

Host: Sillago ciliata.

Locality: Off Dunwich, Moreton Bay $\left(27^{\circ} 29^{\prime} \mathrm{S}\right.$, $\left.153^{\circ} 23^{\prime} \mathrm{E}\right)$.

Voucher specimens: Six specimens in the QM G237291-6.

Representative DNA sequences: ITS2 rDNA, two replicates (one in GenBank MH157060); 28S rDNA, one sequence (GenBank MH157070).
Remark

Gibson (1987) and Bray et al. (1997) reported this species from the golden-line whiting Sillago analis Whitley, S. ciliata and the trumpeter whiting $S$. maculata Quoy \& Gaimard, (Perciformes: Sillaginidae) from Moreton Bay. ITS2 rDNA data were found to be identical for specimens of this species infecting S. ciliata from Moreton Bay and off Heron Island.

\section{Family Aephnidiogenidae Yamaguti, 1934 Genus Austroholorchis Bray \& Cribb, 1997}

\section{Austroholorchis sprenti (Gibson, 1987) Bray \& Cribb, 1997}

Syn. Holorchis sprenti Gibson, 1987

Type-host: Sillago maculata Quoy \& Gaimard (Perciformes: Sillaginidae), trumpeter whiting.

Type-locality: Deception Bay, Moreton Bay.

New records:

Host: Sillago ciliata Cuvier.

Locality: Off Dunwich, Moreton Bay $\left(27^{\circ} 29^{\prime} \mathrm{S}\right.$, $153^{\circ} 23^{\prime} \mathrm{E}$ ).

Voucher material: Seven specimens in the QM G237284-90.

Representative DNA sequences: ITS2 rDNA, four replicates (one in GenBank MH157065); 28S rDNA, one sequence (GenBank MH157075).

Remarks

Gibson (1987) and Bray \& Cribb (1997b) reported this species from Sillago analis, S. ciliata and S. maculata from Moreton Bay. Analyses of the $28 \mathrm{~S}$ data generated during this study indicate that this species forms a strongly-supported clade with all other included aephnidiogenids. Within the aephnidiogenid clade, A. sprenti formed a strongly-supported clade with species of Aephnidiogenes Nicoll, 1915, Holorchis Stossich, 1901 and Neolepocreadium Thomas, 1960, sister to the two freshwater anguilliform-infecting species Stegodexamene anguillae Watson, 1984 and Tetracerasta blepta Watson, 1984. 


\section{Phylogenetic results}

Alignment of the 28S rDNA dataset (Table 2) yielded 1,299 characters (including indels). Deleted ambiguously aligned regions amounted to 49 bases (less than $4 \%$ of the alignment), resulting in a final dataset of 1,250 characters for phylogenetic analysis. Bayesian inference and maximum likelihood analyses of the 28S rDNA dataset resulted in phylograms with almost identical topologies (Fig. 2). Only the relationship between the specimens of Diploproctodaeum monstrosum and Diploproctodaeum cf. monstrosum and that between Lepidapedoides angustus Bray, Cribb \& Barker, 1996 and Preptetos caballeroi Pritchard 1960 were different. The topology was almost identical (but expanded relative) to that found by Bray et al. (2009), in which all lepocreadioid taxa formed a strongly supported clade to the exclusion of cryptogonimid and apocreadiid outgroup taxa. The now seven accepted families each formed monophyletic clades, all of which were strongly supported; nodal support for relationships within the familial clades was lower, especially for those in the lepocreadiid clade. The type- and only species of the Gibsonivermidae formed a well-supported clade with the lepidapedids. Most genera for which there were more than one sequenced species included formed monophyletic clades (Gorgocephalus Manter, 1966, Holorchis, Hypocreadium Ozaki, 1936, Lepidapedon Stafford, 1904, Opechona, Paragyliauchen Yamaguti, 1934 and Proenenterum Manter, 1954), but several formed notably polyphyletic assemblages (Bianium, Diploproctodaeum and Preptetos).

\section{Discussion}

Our phylogenetic hypotheses are inferred from the phylogram generated from the $28 \mathrm{~S}$ rDNA dataset, but all are supported by morphology. This phylogram includes the sequences used by Bray et al. (2009) and Bray \& Cribb (2012) in their reviews of the phylogeny and systematics of lepocreadioids and allows us to set the Moreton Bay worms in context. The uncontroversial results in the tree are the finding of identical sequences for Neomultitestis aspidogastriformis and Clavogalea trachinoti from off Heron Island and in Moreton Bay and the near identical sequences for Multitestis magnacetabulum from the same localities; species of several other trematode families have been shown to be genetically identical between the Great Barrier Reef and Moreton Bay (Brooks et al., 2017; Yong et al., 2018). More controversial is the close molecular similarity of Opechona austrobacillaris from Moreton Bay and O. kahawai from Tasmanian waters, which brings into question the status of these forms. Although morphologically similar, they do appear to be readily distinguishable. Prodistomum keyam, $O$. austrobacillaris and $O$. kahawai are included in a moderately-supported clade, which is poorly resolved internally. Preptetos trulla (Linton, 1907) is in this clade and is clearly not placed in the correct genus given its distance from the type-species, P. caballeroi Pritchard, 1960. Preptetos trulla, Prodistomum keyam, O. austrobacillaris and O. kahawai are also similar morphologically.

Moreton Bay members of the similar, and controversially separated, genera Bianium and Diploproctodaeum formed a well-supported clade, but were internally poorly resolved and clearly need greater sampling, both of species and genes, for a convincing arrangement to emerge. The morphological characteristics that are currently used to separate these genera are evidently unreliable. The five-base difference in sequences between D. monstrosum ('Diploproctodaeum sp.' in Bray et al., 2009) from off Lizard Island and $D$. cf. monstrosum from Moreton Bay indicates that there are potentially two closely related species in Queensland waters. However, few specimens have been collected from either location, and currently there are not enough morphological or molecular data to justify the proposal of a new species; this complex needs further study.

Members of the Lepocreadiidae sensu stricto in Moreton Bay were divided into two major clades reflecting the findings reported by Bray et al. (2009), who labelled the clades as VII and VIII. Clade VII includes what might be considered 'typical' lepocreadiids, mostly occurring in shallow water and, as far as is known, with a gastropod first intermediate host. Clade VIII includes many species from reef fishes, especially tetraodontiform fishes, with just one resolved life-cycle which utilises a bivalve first intermediate host (Hassanine, 2006). The distribution of these clades in terms of their assemblage and the nature of their hosts is worthy of further exploration, but a much wider understanding of the genetic 
Table 2 Collection data and GenBank accession numbers for lepocreadioid species analysed in this study

\begin{tabular}{llll}
\hline Species & Host & GenBank References \\
& & ID
\end{tabular}

\section{Lepocreadioidea}

Aephnidiogenidae Yamaguti, 1934

Aephnidiogenes major Yamaguti, 1934

Austroholorchis sprenti (Gibson, 1987)

Holorchis castex Bray \& Justine, 2007

Holorchis gigas Bray \& Cribb, 2007

Neolepocreadium caballeroi Thomas, 1960

Stegodexamene anguillae Macfarlane, 1951

Tetracerasta blepta Watson, 1984

Enenteridae Yamaguti, 1958

Enenterum aureum Linton, 1910

Koseiria xishaensis Gu \& Shen, 1983

Proenenterum ericotylum Manter, 1954

Proenenterum isocotylum Manter, 1954

Gibsonivermidae n. fam.

Gibsonivermis berryi (Gibson, 1987)

Gorgocephalidae Manter, 1966

Gorgocephalus kyphosi Manter, 1966

Gorgocephalus yaaji Bray \& Cribb, 2005

Gorgocephalus sp.

Diagramma pictum labiosum

(Macleay)

Sillago ciliata Cuvier

Diagramma pictum pictum

(Thunberg)

Plectorhinchus chrysotaenia (Bleeker)

Trachinotus blochii (Lacépède)

Gobiomorphus cotidianus McDowall

Posticobia brazieri (Smith)

Kyphosus vaigiensis (Quoy \& Gaimard)

Kyphosus vaigiensis

Aplodactylus arctidens Richardson

Aplodactylus arctidens

Sillago ciliata

Kyphosus vaigiensis

Kyphosus cinerascens (Forsskål)

Austrolittorina unifasciata (Gray)

Naso tuberosus Lacépède

Pomacanthus sexstriatus (Cuvier)

Centropyge bicolor (Bloch)

Prionurus microlepidotus Lacépède

Sarpa salpa (Linnaeus)

Lagocephalus lunaris (Bloch \& Schneider)

Torquigener pleurogramma (Regan)

Trachinotus coppingeri Günther

Balistoides conspicillum (Bloch \& Schneider)

Ostracion cubicus Linnaeus

Arothron stellatus (Anonymous)

Arothron hispidus (Linnaeus)

Echeneis naucrates Linnaeus
FJ788468 Bray et al. (2009)

MH157075 Present study

FJ788476 Bray et al. (2009)

FJ788477 Bray et al. (2009)

FJ788488 Bray et al. (2009)

KF484005 Herrmann et al. (2014)

FJ788494 Bray et al. (2009)

AY222232 Olson et al. (2003)

AY222233 Olson et al. (2003)

FJ788499 Bray et al. (2009)

FJ788500 Bray et al. (2009)

MH157070 Present study

AY222234 Olson et al. (2003)

KU951489 Huston et al. (2016)

KU951485 Huston et al. (2016)

FJ788501 Bray et al. (2009)

FJ788503 Bray et al. (2009)

FJ788502 Bray et al. (2009)

FJ788504 Bray et al. (2009)

FJ788505 Bray et al. (2009)

MH157076 Present study

MH157066 Present study

MH157067 Present study

FJ788472 Bray et al. (2009)

FJ788474 Bray et al. (2009)

FJ788473 Bray et al. (2009)

MH157069 Present study

FJ788475 Bray et al. (2009) 
Table 2 continued

Species

Hypocreadium picasso Bray, Cribb \& Justine, 2009

Hypocreadium toombo Bray \& Justine, 2006

Lepidapedoides angustus Bray, Cribb \& Barker, 1996

Lepotrema clavatum Ozaki, 1932

Lobatocreadium exiguum (Manter, 1963)

Mobahincia teirae n. g., n. sp.

Multitestis magnacetabulum Mamaev, 1970

Neohypocreadium dorsoporum Machida \& Uchida, 1987

Neomultitestis aspidogastriformis Bray \& Cribb, 2003

Neopreptetos arusettae Machida, 1982

Opechona austrobacillaris Bray \& Cribb, 1998

Opechona kahawai Bray \& Cribb, 2003

Pelopscreadium spongiosum (Bray \& Cribb, 1998)

Preptetos caballeroi Pritchard, 1960

Preptetos trulla (Linton, 1907)

Prodistomum keyam Bray \& Cribb, 1996

Lepidapedidae Yamaguti, 1958

Bulbocirrus aulostomi Yamaguti, 1965

Intusatrium robustum Durio \& Manter, 1968

Lepidapedon beveridgei Campbell \& Bray, 1993

Lepidapedon desclersae Bray \& Gibson, 1995

Lepidapedon discoveryi Bray \& Gibson, 1995

Lepidapedon elongatum (Lebour, 1908)

Lepidapedon gaevskayae Campbell \& Bray, 1993

Lepidapedon rachion (Cobbold, 1858)

Lepidapedon sommervillae Bray \& Gibson, 1995

Lepidapedon zubchenkoi Campbell \& Bray, 1993

Myzoxenus insolens (Crowcroft, 1945)

Neolepidapedon smithi Bray \& Gibson, 1989

Postlepidapedon opisthobifurcatum (Zdzitowiecki, 1990)

Postlepidapedon uberis Bray, Cribb \& Barker, 1997

Profundivermis intercalarius Bray \& Gibson, 1991

\section{Outgroup taxa}

Apocreadiidae Skrjabin, 1942

Homalometron armatum (MacCallum, 1895)

Neoapocreadium splendens Cribb \& Bray, 1999

Paraschistorchis zancli (Hanson, 1953)

Cryptogonimidae Ward, 1917

Acanthochromis polyacanthus
Host

Balistoides viridescens (Bloch \& Schneider)

GenBank References

ID

Rhinecanthus aculeatus (Linnaeus)

Pseudobalistes fuscus (Bloch \& Schneider)

Epinephelus cyanopodus (Richardson) (Bleeker)

Pseudobalistes fuscus

Platax teira (Forsskål)

Platax teira

Chaetodon flavirostris Günther

Platax teira

Pomacanthus sexstriatus

Pomatomus saltatrix Linnaeus

Arripis trutta (Forster)

Ostracion cubicus

Naso vlamingii (Valenciennes)

Ocyurus chrysurus (Bloch)

Monodactylus argenteus (Linnaeus)

Aulostomus chinensis (Linnaeus)

Bodianus perditio (Quoy \& Gaimard)

Coryphaenoides armatus (Hector)

Mora moro (Risso)

Coryphaenoides armatus

Gadus morhua Linnaeus

Coryphaenoides armatus

Gadus morhua

Coryphaenoides guentheri (Vaillant)

Coryphaenoides leptolepis Günther

Notolabrus tetricus (Richardson)

Mora moro

Muraenolepis marmorata Günther

Choerodon venustus (De Vis)

Coryphaenoides armatus

Lepomis microlophus (Günther)

Scolopsis monogramma (Cuvier)

Zanclus cornutus (Linnaeus)
AY222241

Olson et al. (2003)

FJ788478

FJ788479

FJ788480

FJ788482

FJ788483

FJ788484

MH157068

MH157071

FJ788487

MH157072

FJ788490

MH157073

FJ788491

FJ788469

AY222236

AY222237

MH157074

FJ788470

FJ788481

AJ405263

AJ405264

AJ405265

AJ405266

AJ405267

AJ405260

AJ405268

AJ405269

FJ788486

AJ405270

KY497957

AY222242

Olson et al. (2003)

AY222240 Olson et al. (2003)

Bray et al. (2009)

Bray et al. (2009)

Bray et al. (2009)

Bray et al. (2009)

Bray et al. (2009)

Bray et al. (2009)

Present study

Present study

Bray et al. (2009)

Present study

Bray et al. (2009)

Present study

Bray et al. (2009)

Bray et al. (2009)

Olson et al. (2003)

Olson et al. (2003)

Present study

Bray et al. (2009)

Bray et al. (2009)

Bray et al. (2009)

Bray et al. (1999)

Bray et al. (1999)

Bray et al. (1999)

Bray et al. (1999)

Bray et al. (1999)

Bray et al. (1999)

Bray et al. (1999)

Bray et al. (2009)

Bray et al. (1999)

Sokolov et al. (2018)

FJ788492 Bray et al. (2009)

AJ405271 Bray et al. (1999) 
Table 2 continued

\begin{tabular}{|c|c|c|c|}
\hline Species & Host & $\begin{array}{l}\text { GenBank } \\
\text { ID }\end{array}$ & References \\
\hline $\begin{array}{l}\text { Adlardia novaecaledoniae Miller, Bray, Goiran, Justine \& } \\
\text { Cribb, } 2009\end{array}$ & Nemipterus furcosus (Valenciennes) & FJ788496 & Bray et al. (2009) \\
\hline Caecincola parvulus Marshall \& Gilbert, 1905 & Micropterus salmoides (Lacépède) & AY222231 & Olson et al. (2003) \\
\hline
\end{tabular}

structuring of this diverse family is needed before such an analysis can be completed.

The new status of Gibsonivermis, as the type-genus for a monotypic family, has been argued above. This new status is consistent with the observations of Cribb \& Bray (2011) that new trematode families are now principally recognised from among known taxa rather than as a result of completely new discoveries. We suspect that further genetic exploration of unique trematode taxa will likely lead to more families being proposed within the Lepocreadioidea.

Acknowledgements We thank John Page and Dave Thompson for their assistance in the collection of fishes in Moreton Bay, and all members of the Marine Parasitology Research Group at the University of Queensland for assistance with dissections.

Funding RAB, THC and SCC acknowledge the Australian Biological Resources Study (ABRS) for their ongoing support. This study was funded by the ABRS National Taxonomy Research Grant RF215-40.

\section{Compliance with ethical standards}

Conflict of interest The authors declare that they have no conflict of interest.

Ethical approval All applicable institutional, national and international guidelines for the care and use of animals were followed.

Open Access This article is distributed under the terms of the Creative Commons Attribution 4.0 International License (http:// creativecommons.org/licenses/by/4.0/), which permits unrestricted use, distribution, and reproduction in any medium, provided you give appropriate credit to the original author(s) and the source, provide a link to the Creative Commons license, and indicate if changes were made.

\section{References}

Aken'Ova, T. O. (2003). A new species of Podocotyloides Yamaguti, 1934 (Digenea: Opecoelidae) from a Western
Australian temperate marine fish. Systematic Parasitology, 55, 127-133.

Aken'Ova, T. O., Cribb, T. H., \& Bray, R. A. (2008). Eight new species of Macvicaria Gibson and Bray, 1982 (Digenea: Opecoelidae) mainly from endemic temperate marine fishes of Australia. ZooKeys, 1, 23-58.

Ankenbrand, M. J., Keller, A., Wolf, M., Schultz, J., \& Förster, F. (2015). ITS2 Database V: Twice as much. Molecular Biology and Evolution, 32, 3030-3032.

Barker, S. C., Blair, D., Garrett, A. R., \& Cribb, T. H. (1993). Utility of the D1 domain of nuclear 28S rRNA for phylogenetic inference in the Digenea. Systematic Parasitology, 26, 181-188.

Blasco-Costa, I., Cutmore, S. C., Miller, T. L., \& Nolan, M. J. (2016). Molecular approaches to trematode systematics: 'best practice' and implications for future study. Systematic Parasitology, 93, 295-306.

Bray, R. A. (2005). Family Lepocreadiidae Odhner, 1905. In: Jones, A., Bray, R. A. \& Gibson, D. I. (Eds), Keys to the Trematoda. Volume 2. Wallingford: CABI Publishing and The Natural History Museum, pp. 545-602.

Bray, R. A., \& Cribb, T. H. (1996). Two species of Prodistomum Linton, 1910 (Digenea: Lepocreadiidae) from marine fishes of Australia. Systematic Parasitology, 35, 59-67.

Bray, R. A., \& Cribb, T. H. (1997a). Lepocreadiid (Digenea) species from members of the marine teleost family Cheilodactylidae from south-western Australia, including four new genera and five new species. Systematic Parasitology, 37, 27-45.

Bray, R. A., \& Cribb, T. H. (1997b). The subfamily Aephnidiogeninae Yamaguti, 1934 (Digenea: Lepocreadiidae), its status and that of the genera Aephnidiogenes Nicoll, 1915, Holorchis Stossich, 1901, Austroholorchis n. g., Pseudaephnidiogenes Yamaguti, 1971, Pseudoholorchis Yamaguti, 1958 and Neolepocreadium Thomas, 1960. Systematic Parasitology, 36, 47-68.

Bray, R. A., \& Cribb, T. H. (1998). Lepocreadiidae (Digenea) of Australian coastal fishes: new species of Opechona Looss, 1907, Lepotrema Ozaki, 1932 and Bianium Stunkard, 1930 and comments on other species reported for the first time or poorly known in Australian waters. Systematic Parasitology, 41, 123-148.

Bray, R. A., \& Cribb, T. H. (2001). Amphicreadium n. g. (Digenea: Lepocreadiidae) from monacanthid fishes (Tetraodontiformes) from the coast of northern Tasmania. Systematic Parasitology, 49, 205-209.

Bray, R. A., \& Cribb, T. H. (2003a). Lepocreadiidae (Digenea) from the batfish of the genus Platax Cuvier (Teleostei: Ephippidae) from the southern Great Barrier Reef, Queensland, Australia. Systematic Parasitology, 55, 1-9. 
Bray, R. A., \& Cribb, T. H. (2003b). New species of Opechona Looss, 1907 and Cephalolepidapedon Yamaguti, 1970 (Digenea: Lepocreadiidae) from fishes off northern Tasmania. Papers and Proceedings of the Royal Society of Tasmania, 137, 1-5.

Bray, R. A., \& Cribb, T. H. (2012). Reorganisation of the superfamily Lepocreadioidea Odhner, 1905 based on an inferred molecular phylogeny. Systematic Parasitology, 83, 169-177.

Bray, R. A., Cribb, T. H., \& Barker, S. C. (1997). Postlepidapedon Zdzitowiecki, 1993 and Gibsonivermis n. g. (Digenea: Lepocreadiidae) from fishes of the southern Great Barrier Reef, Australia, and their relationship to Intusatrium Durio \& Manter, 1968. Systematic Parasitology, 36, 143-155.

Bray, R. A., Cribb, T. H., \& Justine, J.-L. (2010a). Diploproctodaeum spp. (Digenea, Lepocreadiidae) in Australian and New Caledonian waters including two new species from Tetraodontiformes and new records of related species. Acta Parasitologica, 55, 313-326.

Bray, R. A., Cribb, T. H., \& Justine, J.-L. (2010b). Multitestis Manter 1931 (Digenea: Lepocreadiidae) in ephippid and chaetodontid fishes (Perciformes) in the south-western Pacific Ocean and the Indian Ocean off Western Australia. Zootaxa, 2427, 36-46.

Bray, R. A., Cribb, T. H., \& Pichelin, S. P. (1999). Two new species of lepidapedines (Digenea, Lepocreadiidae) from the King George whiting Sillaginodes punctata (Perciformes, Sillaginidae) from off Kangaroo Island, South Australia. Acta Parasitologica, 44, 108-114.

Bray, R. A., \& Gibson, D. I. (1990). The Lepocreadiidae (Digenea) of fishes of the north-east Atlantic: review of the genera Opechona Looss, 1907 and Prodistomum Linton, 1910. Systematic Parasitology, 15, 159-202.

Bray, R. A., \& Justine, J.-L. (2012). A review of the Lepocreadiidae (Digenea, Lepocreadioidea) from fishes of the waters around New Caledonia. Acta Parasitologica, 57, 247-272.

Bray, R. A., Waeschenbach, A., Cribb, T. H., Weedall, G. D., Dyal, P., \& Littlewood, D. T. J. (2009). The phylogeny of the Lepocreadioidea (Platyhelminthes: Digenea) inferred from nuclear and mitochondrial genes: implications for their systematics and evolution. Acta Parasitologica, 54, 310-329.

Brooks, X., Cribb, T. H., Yong, R. Q.-Y., \& Cutmore, S. C. (2017). A re-evaluation of diversity of the Aporocotylidae Odhner, 1912 in Siganus fuscescens (Houttuyn) (Perciformes: Siganidae) and associated species. Systematic Parasitology, 94, 717-737.

Cribb, T. H., Anderson, G. R., Adlard, R. D., \& Bray, R. A. (1998). A DNA-based demonstration of a three-host lifecycle for the Bivesiculidae (Platyhelminthes: Digenea). International Journal for Parasitology, 28, 1791-1795.

Cribb, T. H., \& Bray, R. A. (2010). Gut wash, body soak, blender and heat-fixation: approaches to the effective collection, fixation and preservation of trematodes of fishes. Systematic Parasitology, 76, 1-7.

Cribb, T. H., \& Bray, R. A. (2011). Trematode families and genera: have we found them all? Trends in Parasitology, 27, 149-154.
Cutmore, S. C., Diggles, B. K., \& Cribb, T. H. (2016). Transversotrema Witenberg, 1944 (Trematoda: Transversotrematidae) from inshore fishes of Australia: description of a new species and significant range extensions for three congeners. Systematic Parasitology, 93, 639-652.

Darriba, D., Taboada, G. L., Doallo, R., \& Posada, D. (2012). jModelTest 2: more models, new heuristics and parallel computing. Nature Methods, 9, 772.

Edgar, R. C. (2004). MUSCLE: multiple sequence alignment with high accuracy and high throughput. Nucleic Acids Research, 32, 1792-1797.

Gibson, D. I. (1987). Two new lepocreadiids (Digenea) from Sillago spp. (Pisces: Sillaginidae) in Australian waters. Journal of Natural History, 21, 159-166.

Hafeezullah, M. (1970). Lepocreadid trematodes of marine fishes of India. Parasitology, 61, 345-356.

Hassanine, R. M. E.-S. (2006). The life cycle of Diploproctodaeum arothroni Bray and Nahhas, 1998 (Digenea: Lepocreadiidae), with a comment on the parasitic castration of its molluscan intermediate host. Journal of Natural History, 40, 1211-1222.

Herrmann, K. K., Poulin, R., Keeney, D. B., \& Blasco-Costa, I. (2014). Genetic structure in a progenetic trematode: signs of cryptic species with contrasting reproductive strategies. International Journal for Parasitology, 44, 811-818.

Huston, D. C., Cutmore, S. C., \& Cribb, T. H. (2016). The lifecycle of Gorgocephalus yaaji Bray \& Cribb, 2005 (Digenea: Gorgocephalidae) with a review of the first intermediate hosts for the superfamily Lepocreadioidea Odhner, 1905. Systematic Parasitology, 93, 653-665.

ICZN (2012). International Commission on Zoological Nomenclature: Amendment of articles 8, 9, 10, 21 and 78 of the International Code of Zoological Nomenclature to expand and refine methods of publication. Bulletin of Zoological Nomenclature, 69, 161-169.

Kearse, M., Moir, R., Wilson, A., Stones-Havas, S., Cheung, M., Sturrock, S., et al. (2012). Geneious Basic: an integrated and extendable desktop software platform for the organization and analysis of sequence data. Bioinformatics, 28, 1647-1649.

Keller, A., Schleicher, T., Schultz, J., Müller, T., Dandekar, T., \& Wolf, M. (2009). 5.8S-28S rRNA interaction and HMMbased ITS2 annotation. Gene, 430, 50-57.

Kruse, G. O. W. (1978). Trematodes of marine fishes from South Australia. 1. Paraneocreadium australiense gen. et sp. n. (Lepocreadiidae). Journal of Parasitology, 64, 398-400.

Kruse, G. O. W. (1979). Trematodes of marine fishes from South Australia. 4. Harveytrema bisulcatum gen. et sp. n. (Lepocreadiidae). Journal of Parasitology, 65, 918-920.

Linton, E. (1928). Notes on trematode parasites of birds. Proceedings of the United States National Museum, 73, 1-36.

Littlewood, D. T. J. (1994). Molecular phylogenetics of cupped oysters based on partial 28S rRNA gene sequences. Molecular Phylogenetics and Evolution, 3, 221-229.

Littlewood, D. T. J., Curini-Galletti, M., \& Herniou, E. A. (2000). The interrelationships of Proseriata (Platyhelminthes: Seriata) tested with molecules and morphology. Molecular Phylogenetics and Evolution, 16, 449-466.

Littlewood, D. T. J., Rohde, K., \& Clough, K. A. (1997). Parasite speciation within or between host species? 
Phylogenetic evidence from site-specific polystome monogeneans. International Journal for Parasitology, 27, 1289-1297.

Machida, M. (1982). Lepocreadiid trematodes from marine fishes of Palau. Proceedings of the Japanese Society of Systematic Zoology, 23, 1-11.

Maddison, W. P., \& Maddison, D. R. (2017). Mesquite: a modular system for evolutionary analysis. Version 3.01 http://mesquiteproject.org.

Mamaev, Y. L. (1970). [Helminths of some commercial fishes in the Gulf of Tong King.] In: Oshmarin, P. G., Mamaev, Y. L. \& Lebedev, B. I. (Eds), Helminths of Animals of SouthEast Asia. Moscow: Izdatel'stvo Nauka, pp. 127-190 (In Russian).

Miller, M. A., Pfeiler, E., \& Schwartz, T. (2010). Creating the CIPRES Science Gateway for inference of large phylogenetic trees. In: Proceedings of the Gateway Computing Environments Workshop (GCE), 14 Nov. 2010, New Orleans, LA, pp. 1-8.

Morgan, J. A., \& Blair, D. (1995). Nuclear rDNA ITS sequence variation in the trematode genus Echinostoma: An aid to establishing relationships within the 37-collar-spine group. Parasitology, 111, 609-615.

Olson, P. D., Cribb, T. H., Tkach, V. V., Bray, R. A., \& Littlewood, D. T. J. (2003). Phylogeny and classification of the Digenea (Platyhelminthes: Trematoda). International Journal for Parasitology, 33, 733-755.

Ronquist, F., Teslenko, M., van der Mark, P., Ayres, D. L., Darling, A., Höhna, S., et al. (2012). MrBayes 3.2: efficient Bayesian phylogenetic inference and model choice across a large model space. Systematic Biology, 61, 539-542.
Sey, O. (1996). Description of Bianium arabicum sp. n. (Trematoda, Lepocreadiidae) from the pufferfish, Lagocephalus lunaris (Bloch et Schneider, 1801) in Kuwait and a review of the genus Bianium Stunkard, 1930. Parasitologia Hungarica, 28, 13-20.

Shen, J.-W., \& Tong, Y.-Y. (1990). Studies on the digenetic trematodes of fishes from the Daya Bay (Trematoda). Acta Zootaxonomica Sinica, 15, 385-392 (In Chinese).

Snyder, S. D., \& Tkach, V. V. (2001). Phylogenetic and biogeographical relationships among some Holarctic frog lung flukes (Digenea: Haematoloechidae). Journal of Parasitology, 87, 1433-1440.

Sokolov, S. G., Khasanov, F. K., \& Gordeev, I. I. (2018). New data on the morphology and phylogenetic connections of Postlepidapedon opisthobifurcatum (Trematoda, Lepocreadioidea: Lepidapedidae), a parasite of Antarctic and sub-Antarctic fishes. Helminthologia, 55, 95-101.

Stamatakis, A. (2014). RAxML Version 8: A tool for phylogenetic analysis and post-analysis of large phylogenies. Bioinformatics, 30, 1312-1313.

Sun, D., Bray, R. A., Yong, R. Q., Cutmore, S. C., \& Cribb, T. H. (2014). Pseudobacciger cheneyae n. sp. (Digenea: Gymnophalloidea) from Weber's chromis (Chromis weberi Fowler \& Bean) (Perciformes: Pomacentridae) at Lizard Island, Great Barrier Reef, Australia. Systematic Parasitology, 88, 141-152.

Yong, R. Q.-Y., Cutmore, S. C., Jones, M. K., Gauthier, A. R. G., \& Cribb, T. H. (2018). A complex of the blood fluke genus Psettarium (Digenea: Aporocotylidae) infecting tetraodontiform fishes of east Queensland waters. Parasitology International, 67, 321-340. 